\title{
Immunocytochemical Localization of Synaptophysin on the Smooth-Surfaced Tubular Membranes Present in Nerve Terminal and Preterminal Areas in the Rat Cerebellar Cortex*
}

\author{
Tomoko KAdota $^{1}$, Mitsuaki Fujita ${ }^{1}$ and Ken KADOTA ${ }^{2}$ \\ Department of Anatomy ${ }^{1}$, Chiba University School of Medicine, Chiba; and Department of Neurochemistry ${ }^{2}$, Psychiatric Research \\ Institute of Tokyo, Tokyo, Japan
}

Received June 24, 1991

\begin{abstract}
Summary. The distribution of synaptophysin, a major protein of the synaptic vesicle membrane, was immunocytochemically examined in the rat cerebellar cortex. A monoclonal antibody against synaptophysin recognized the epitope to be present in the presynaptic membranous structures including synaptic vesicles, presynaptic membrane, coated vesicles, and vacuoles of endocytotic origin. In the nerve terminal as well as preterminal areas, the antibody labeled the smooth-surfaced tubular membranes which were located in the relatively interior parts of these areas and consistent in size and appearance with the short tubules comprising the thinner parts of the axonal reticulum. However, the antibody did not stain the short tubular membranes, though similar in appearance to the above, which existed right below the axolemma in the preterminal and nerve terminal areas. The results are discussed with special reference to the precursor membrane compartments of synaptic vesicles.
\end{abstract}

Synaptic vesicles play a key role in neurotransmission and in membrane movements in the nerve terminal. It has been suggested that neurotransmitters stocked in them are released by exocytosis, leading to presynaptic membrane movements involving exocytosis-endocytosis coupling and the axonal smooth endoplasmic reticulum (ZIMMERMANN, 1979; HolTZ. MAN, 1981). Recently, several research groups have prepared monoclonal antibodies against the component proteins of the synaptic vesicle membrane, synaptophysin, p65 and SV2, with molecular weights of 38,65 and $100 \mathrm{KD}$, respectively (CARLSON and
Kelly, 1980; MATthew et al., 1981; WiedenmanN and Franke, 1985; NAVONE et al., 1986; OBATA et al., 1987). BUCKLEY and KeLly (1985) stained synaptic vesicles and presynaptic membrane with an antibody to synaptophysin, thereby presenting evidence supporting the exocytosis of synaptic vesicles followed by incorporation of the vesicle membrane into the presynaptic membrane. Although the nerve endings have been well examined with the antibodies, the axon and the preterminal area remain to be precisely studied by immunocytochemistry for identifying the membrane structures with corresponding epitopes.

Earlier cytochemical works with heavy metals have suggested that the thin parts, short in length and tubulosaccular in appearance, of the smooth endoplasmic reticulum (SER) in the axon, pass by the preterminal area, enter the nerve terminal, and serve there as a major source of synaptic vesicles by budding off the vesicular structures (DROZ et al., 1975; REINICKE and WALTHER, 1978; HoltzMAN and MERCURIO, 1980; KADOTA and KADOTA, 1985). However, it has not been determined yet whether the axonal SER contains the components of synaptic vesicle membrane. The ultrastructure and biochemical nature of the axonal SER remained to be characterized. The present work aims to examine immunocytochemically the details of the association of synaptophysin with the axonal SER, which until now have been cytochemically observed as smooth-surfaced tubular membranes in the preterminal and nerve terminal areas.

\footnotetext{
*This study was supported partially by grants from the Ministry of Education, Science and Culture, Japan, the Naito Foundation (to T.K.) and the Uehara foundation (to K. K.).
} 


\section{MATERIALS AND METHODS}

\section{Monoclonal antibody}

A monoclonal antibody to synaptophysin was prepared. A purified synaptic vesicle fraction was prepared as the antigen material from whole rat brains with modifications of our previous procedures (KADOTA et al., 1976). Briefly, synaptic vesicles were extracted from crude synaptosomes by hypo-osmotic treatment and then subjected to differential and sucrose density gradient centrifugation for purification. The synaptic vesicle fraction $\left(\mathrm{S}_{5} \mathrm{P}\right)$ was suspended in a buffer solution of $10 \mathrm{mM}$ 2-(N-porpholino) ethansulfonic acid (MES) at $\mathrm{pH} 6.0\left(\mathrm{ml} / 5\right.$ brains), and stored at $-70^{\circ} \mathrm{C}$ for $1-4$ days. The specimens were then thawed, and $4 \mathrm{ml}$ was layered on a sucrose density gradient consisting of 8 $\mathrm{ml}$ of $16 \%$ and $26 \mathrm{ml}$ of $24 \%$ sucrose in MES in $40 \mathrm{ml}$ tubes in a Hitachi RPS $27-2$ swing bucket rotor. The tubes were centrifuged at $60,000 \mathrm{~g}$ for $2 \mathrm{~h}$. The $16 \%$ layer, excluding the lowest part in contact with the $24 \%$ layer, was collected as a purified synaptic vesicle fraction, negatively stained, and examined by electron microscopy. The obtained fraction was of a very high purity. The materials were diluted two times with the addition of equal amounts of MES and centrifuged at $180,000 \mathrm{~g}$ for $1 \mathrm{~h}$. The precipitate was resuspended in a minimum volume of MES to then serve as the antigen material. If further purification was needed, $10 \mathrm{ml}$ of the double-diluted synaptic vesicle preparation (the 16\% layer) was layered on a sucrose density gradient consisting of $9 \mathrm{ml}$ each of $16 \%, 24 \%$ and $40 \%$ sucrose in MES. The density was spun at $60,000 \mathrm{~g}$ for $16 \mathrm{~h}$ and the interface band between $24 \%$ and $40 \%$ was harvested as a further purified synaptic vesicle fraction.

$\mathrm{BALB} / \mathrm{c}$ mice were immunized according to methods by Mishell and SHIIGI (1981). The splenocytes from the mice were fused with myeloma P3U1. Hybridoma antibodies were screened by ELISA (enzyme-linked immunosorbent assay). The antibody which recognized the polypeptide with a molecular weight of $38 \mathrm{KD}$ in the synaptic vesicle fraction was selected as the antibody for synaptophysin by SDSPAGE and immunoblot methods. This antibody was used for the immunohistochemical localization of the polypeptide in the rat cerebellar cortex. The antibody clearly labeled the large glomeruli in the granular layer and small punctates in the molecular layer. These biochemical and histochemical properties of the antibody resembled those of the monoclonal antibody to synaptophysin characterized by previous investigators (WIEDENMANN and FRANKE, 1985; NAVONE et al., 1986; OBATA, et al., 1987).

\section{Immuno-electron microscopy}

Adult rats were fixed by perfusion via the left ventricle with a mixture of $4 \%$ paraformaldehyde and $0.1 \%$ glutaraldehyde in $0.1 \mathrm{M}$ phosphate buffer $(\mathrm{PB})$ at $\mathrm{pH}$ 7.4. The cerebellar cortex was dissected out and cut in sagittal planes into sections $20 \mu \mathrm{m}$ thick with a microslicer (Dosaka Instruments, Japan). The slices were incubated with the antibody for $4-16 \mathrm{~h}$ at $4^{\circ} \mathrm{C}$ after blocking with $1 \%$ bovine serum albumin. The materials were rinsed in phosphate buffered saline (PBS), and then incubated with a second antibody, biotinylated horse antimouse IgG (Vector Lab. Inc. USA) for 2-3 $\mathrm{h}$. The sections were then reacted with $\mathrm{ABC}$ reagent (Vector Lab. Inc. USA), rinsed with 0.05 $\mathrm{M}$ Tris- $\mathrm{HCl}$ buffer ( $\mathrm{pH}$ 7.6) and incubated with DABreagent $(0.1 \%$ diaminobenzidine tetrahydrochloride in Tris-buffer containing $0.02 \% \mathrm{H}_{2} \mathrm{O}_{2}$ ) for $30 \mathrm{~min}$ at room temperature. After rinsing with $\mathrm{PBS}$, the slices were postfixed with $1 \%$ osmium tetroxide in $\mathrm{PB}$ and stained en bloc with $1 \%$ uranyl acetate in $50 \mathrm{mM}$ acetate buffer, $\mathrm{pH} 5.2$, for $14-16 \mathrm{~h}$ at $4{ }^{\circ} \mathrm{C}$. Subsequently the specimens were dehydrated with a series of graded ethanol solutions and embedded in Epon 812. Some ultrathin sections were lightly stained with lead citrate while others were not. They were examined with an electron microscope JEM 1200 EX.

Figs. 1-5. Electron micrographs showing the localization of synaptophysin in the molecular layer of the rat cerebellar cortex. Labeled with a monoclonal antibody to synaptophysin, a synaptic vesicle membrane protein with a M.W. of 38 KD. Lightly stained with lead citrate except Figure 2.

Fig. 1. Molecular layer at a low magnification. Various types of nerve endings $(T)$ are strongly labeled. $\times 30,000$

Fig. 2. High power electron micrograph showing that the synaptic vesicles $(S V)$ and presynaptic membrane are strongly labeled. Intraterminal vacuoles $(V)$ occurring on the outskirts of the synaptic vesicle accumulation are labeled. A smooth-surfaced tubular membrane (arrow) is weakly labeled in the preterminal area on the top right. The section was not stained with lead citrate. $\times 40,000$ 


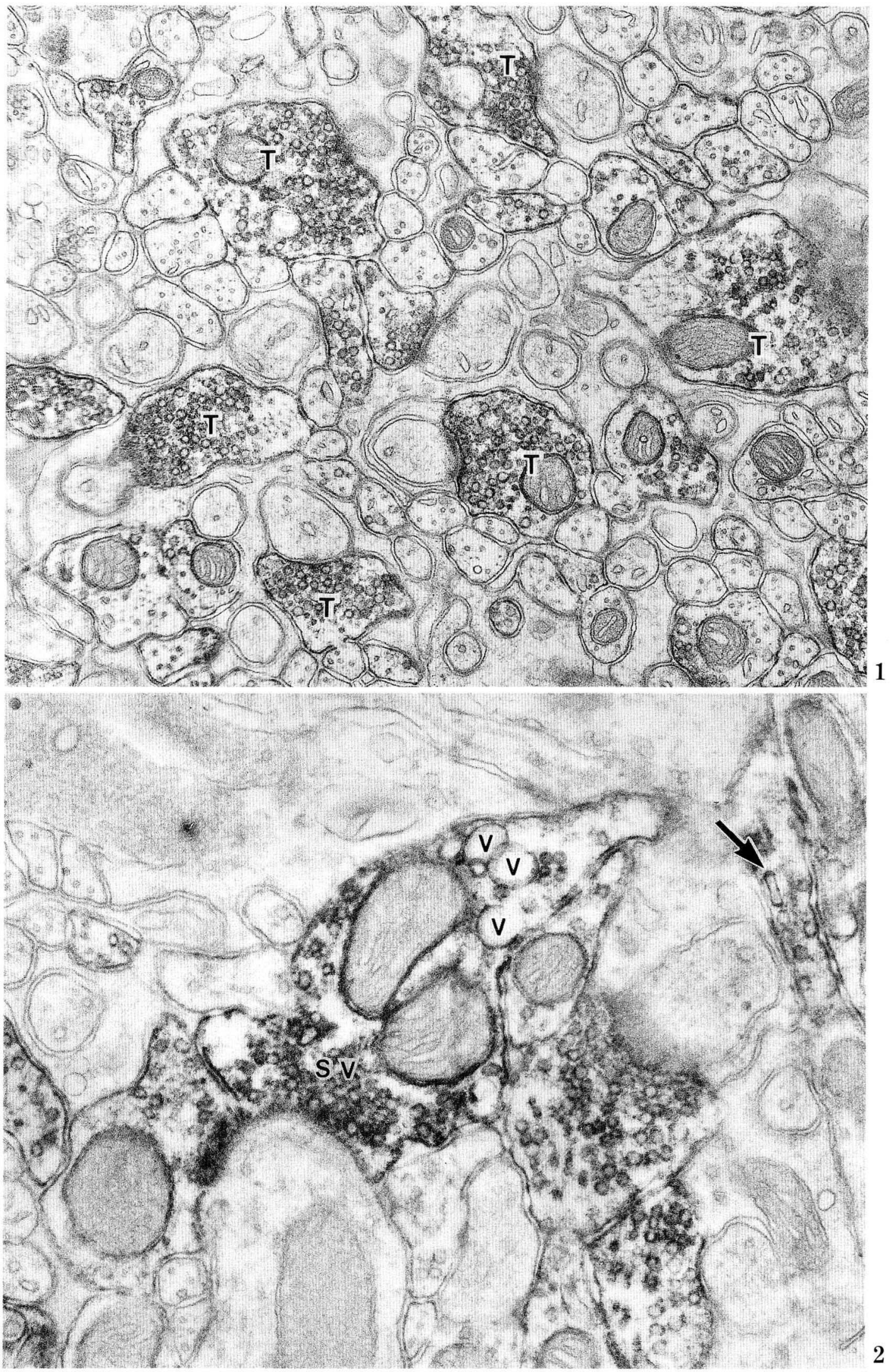

Figs. 1 and 2 . Legends on the opposite page. 


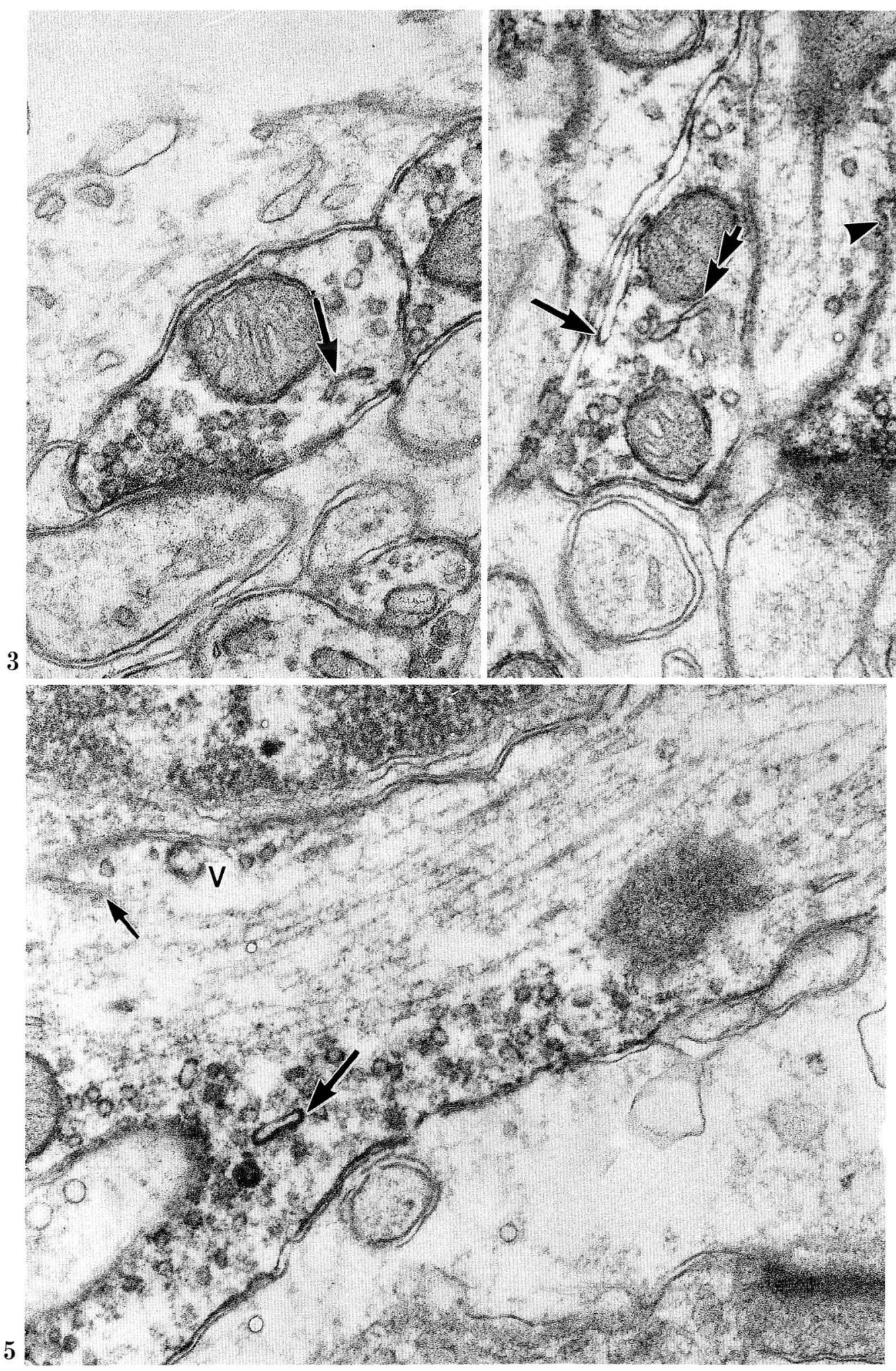

Figs. 3-5. Legends on the opposite page. 


\section{RESULTS}

\section{Subsynaptic localization of synaptophysin}

To identify the subsynaptic localization of synaptophysin, we immunocytochemically examined the cerebellar cortex with an electron microscope. Reaction products with the antibody were found in every kind of nerve terminal in the cortex: mossy nerve endings and Golgi Type II terminals in the granular layer, and climbing fiber terminals, parallel fiber terminals and other kinds of small nerve terminals in the molecular layer (Fig. 1). However, no labeling was found in the axon or in the postsynaptic dendrites.

High power electron micrographs more clearly delineated the subcellular localization of synaptophysin (Figs. 2-5). The reaction products were concentrated on the membrane of synaptic vesicles and on the presynaptic membrane (Figs. 1-3, 5). In addition, intraterminal vacuoles and coated vesicles, near the synaptic vesicle clusters, were labeled with the antibody (Figs. 2, 4, 5). On the other hand, as shown in Figures 4 and 5, the antibody marked the vacuoles and a coated pit which were distributed apart from the synaptic vesicle clusters, presenting a labeling pattern unlikely to result from the diffusion of the immunocytochemical precipitates from the synaptic vesicles. No labeling was found on the axolemma except the terminal area and postsynaptic membrane (Figs. 1, 2).

The smooth-surfaced tubular membranes near or among synaptic vesicles were intensely labeled in the nerve terminal (Figs. 3, 5; large arrows). A long tubule, similar in shape to the axonal SER and a little apart from synaptic vesicle clusters, was weakly labeled in the preterminal area (Fig. 4). In contrast, the short tubular structures lying just below the axolemma were not stained in the preterminal and nerve terminal areas (small arrow, Fig. 5).

Mitochondria in the nerve terminal were often labeled. However, the reaction product was often precipitated on their surface apposing the synaptic vesicle clusters. Mitochondria distributed in the axon, perikaryon and dendrite were not labeled (Figs. 1-5). From this staining pattern it is doubtful that the labeling of mitochondria is related to the epitope of synaptophysin present in this organella.

\section{DISCUSSION}

We prepared a monoclonal antibody to a component protein of the synaptic vesicle membrane, synaptophysin, with a molecular weight of $38 \mathrm{KD}$. The subcellular localization of this protein was immunocytochemically examined by electron microscopy in the rat cerebellar cortex. The morphology of the smoothsurfaced tubular membranes was scrutinized with the antibody with special reference to the axonal smooth endoplasmic reticulum and synaptic vesicles.

Synaptophysin has been selectively localized on the synaptic vesicle membrane (JAHN et al., 1985; WIEDENMANN and FRANKE, 1985) and simultaneously on the presynaptic membrane which was more intensely labeled with the antibody following stimulation (VON WEDEL et al., 1981; BUCKLEY et al., 1983; Robitaille and TREMBley, 1987; VAltorta et al., 1988). The present study has confirmed these earlier findings and supported the concept that the synaptic vesicle membrane is fused with and then incorporated into the presynaptic membrane by exocytosis (HEUSER and REESE, 1973; CECCARELli et al., 1973; HEUSER et al., 1979; LENZ and CHESTER, 1982).

Coated vesicles were labeled with the antibody confirming previous reports (PFEFFER and KELLY, 1985; WIEDENMANN et al., 1985; TIXIER-VIDAL et al., 1988), suggesting that they transiently perticipate in the vesicular traffic involving synaptic vesicles. The antibody conjugated with colloidal gold, however, failed to label the coated vesicles in the nerve terminals (WIEDEN MANN and FRANKE, 1985; NAVONE et al., 1986) or in the PC-12 cells. The absence of anti-synaptophysin labeling on coated membranes in these experiments may be due to limited accessibility for gold particles (JANETZKo et al., 1989).

Synaptophysin was present on the intraterminal vacuoles apparently of macropinocytotic origin (KADOTA and KADOTA, 1982). The protein was also found on plasmalemmal invaginations (WIEDENMAN and FrANKE, 1985; NAVONE et al., 1986). These findings strongly support our previous suggestion that the macropinocytotic vacuoles - but not coated vesicles - in the nerve terminal work as a primary device to remove rapidly the excess of terminal

Fig. 3. A short tubule (arrow) labeled in a small nerve terminal. $\times 50,000$

Fig. 4. A long tubule (arrow) located at the left end in a preterminal area is partially labeled. A short tubule is weakly labeled (double arrow). A coated pit invaginating from the axolemma is labeled in a neighboring process (arrowhead). $\times 50,000$

Fig. 5. A short tubule lying in a cluster of synaptic vesicles is strongly labeled (large arrow) in a large nerve terminal. A C-shaped vacuole $(V)$ on the top left is also labeled. A short tubule located below the axolemma (small arrow) is not labeled. $\times 48,000$ 
surface membrane containing the synaptic vesiclemembrane proteins (KADOTA and KADOTA, 1982). A recent report on synaptophysin expression on the endosomes in the PC-12 cells supports this suggestion (Clift-O'Grady et al., 1990).

The antibody to synaptophysin also labeled the smooth-surfaced tubular membranes, short in length, which were present in the relatively interior parts of the nerve terminal and preterminal areas, but not those localized near the axolemma. These short and tubular smooth-surfaced membranes located in the preterminal area as well as in the nerve terminal have been suggested ultrastructurally and histochemically to originate from the axonal SER (PALAY, 1958; DROZ et al., 1975; REINICKE and WALTHER, 1978; KADOTA and KADOTA, 1985). Moreover, the axonal SER has been shown to share histochemical properties with synaptic vesicles (DROZ et al., 1975; REINICKE and WALTHER, 1978; HOLTZMAN and MERCURIO, 1980; KADOTA and KADOTA, 1985). DROZ et al. (1975) have suggested that the axonal SER composes a continuous three-dimensional network passing through the preterminal area and ends in the nerve terminal to supply synaptic vesicles. The present authors have reported that the thin tubular network of the axonal SER increasingly enters the preterminal area and the nerve ending during transmitter release, where vesicular structures, indistinguishable in size and appearance from the synaptic vesicles, are budded off from the short and tubular smooth-surfaced membranes of the SER (KADOTA and KADOTA, 1985). These short tubular membranes of the SER are morphologically consistent with the smooth-surfaced tubular membranes shown in the present study, which are positively stained with the antibody to synaptophysin and occupy interior portions of the nerve terminal and the preterminal areas. Similar observations, however, were not available from the short tubules lying directly below the axolemma. Taken together, the short tubular membranes in the preterminal area and the axon ending would be immunoytochemically divided into two subclasses; one of these, positively labeled with the antibody, is related to synaptic vesicles and involved in the presynaptic membrane movements, and the other occurring below the axolemma is not. Alternatively, the latter might be too immature to be labeled with the antibody.

Some investigators have examined the intracellular localization of synaptophysin in immature neurons, and demonstrated that this protein was present on the innermost cisterns of the Golgi apparatus, and also on the numerous small vesicles near this organelle (NAVONE et al., 1986; TIXIER-VIDAL et al., 1988). They supposed that synaptophysin was releas- ed from the Golgi apparatus in a vesicular form after glycosylation and then transported to the nerve terminal. The workers also observed that the short tubular membranes containing synaptophysin localized near the small vesicles. However, these groups did not determine a transporting pathway of synaptophysin in the axon. A recent report showed the immunocytochemical localization of a synaptic vesicle membrane protein, termed "SV2", on the vesiculotubular structures in the axon and the nerve terminal (JANETZKO et al., 1989). This work has claimed that the vesiculo-tubular structures compose a membrane compartment of synaptic vesicles different from the axonal reticulum described by the preceding investigators (DROZ et al., 1975; RAMBOURG and DROZ, 1980; KADOTA and KADOTA, 1985). In short, the arguments concerning the precursor membrane structures for synaptic vesicles are still controversial. At present, it remains unclear whether or not tubular membranes in the preterminal and terminal areas shown in the present report are relevant to the vesiculo-tubular structures (JANETZKO et al., 1989).

Acknowledgements. The authors are grateful to Prof. Y. SHIMADA for his generous support, Mr. NAKAMURA for the photographic work and Mrs. Shimizu for typing. We express our appreciation to Prof. K. OBATA for giving us the antibody to synaptophysin to facilitate the characterization of our antibody employed in the present work.

\section{REFERENCES}

BUCKLEY, K. and R. B. KELLY: Identification of a transmembrane glycoprotein specific for secretory vesicles of neural and endocrine cells. J. Cell Biol. 100: 12841294 (1985).

Buckley, K. M., E. S. Schweitzer, G. P. Miljanich, L. Clift-O'Grady, P. D. Kushner, L. F. Reichardt and R. B. KeLLY: A synaptic vesicle antigen is restricted to the junctional region of the presynaptic plasma membrane. Proc. Nat. Acad. Sci. USA 80: 7342-7346 (1983).

Carlson, S. S. and R. B. Kelly: An antiserum specific for cholinergic synaptic vesicles from electric organ. J. Cell Biol. 87: 98-103 (1980).

Ceccarelli, B., W. P. Hurlbut and A. Mauro: Turnover of transmitter and synaptic vesicles at the frog neuromuscular junction. J: Cell Biol. 57: 499-524 (1973).

Clift-O'Grady, L., A. D. LinstedT, A. W. Lowe, E. Grote and R. B. KELLY: Biogenesis of synaptic vesicle-like structures in a pheochromocytoma cell line PC-12. J. Cell Biol. 110: 1693-1703 (1990).

Droz, B., A. Rambourg and H. L. Koenig: The smooth endoplasmic reticulum: structure and role in the renewal of axonal membrane and synaptic vesicles by fast axonal transport. Brain Res. 93: 1-13 (1975). 
Heuser, J. E. and T. S. REESE: Evidence for recycling of synaptic vesicle membrane during transmitter release at the frog neuromuscular junction. J. Cell Biol. 57: 315344 (1973).

Heuser, J. E., T. S. Reese, M. J. Dennis, Y. JAN, L. JAN and L. Evans: Synaptic vesicle exocytosis captured by quick freezing and correlated with quantal transmitter release. J. Cell Biol. 81: 275-300 (1979).

Holtzman, E.: Membrane circulation: an overview. In: Methods in cell biology, Vol. 23. Academic Press Inc., 1981 (p. 379-397).

Holtzman, E. and A. M. Mercurio: Membrane circulation in neurons and photoreceptors: Some unsolved issues. Int. Rev. Cytol. 67: 1-67 (1980).

Jahn, R., W. Schiebler, C. Quimet and P. Greengard: A 38,000-dalton membrane protein (p38) present in synaptic vesicles. Proc. Nat. Acad. Sci. USA 82: 41374141 (1985).

JanetZKo, A., H. Zimmermann and W. VolknandT: Interneuronal distribution of a synaptic vesicle membrane protein: Antibody binding sites at axonal membrane compartments and trans-Golgi network and accumulation at nodes of Ranvier. Neuroscience 32: 65-77 (1989).

Kadota, T., K. Kadota and E. G. Gray: Coated vesicle shells, particle/chain materials, and tubulin in brain synaptosomes. An electron microscopical and biochemical study. J. Cell Biol. 69: 608-621 (1976).

Kadota, T. and K. Kadota: Membrane retrieval by macropinocytosis in presynaptic terminals during transmitter release in cat sympathetic ganglion in situ. J. Electron Microsc. 31: 73-80 (1982).

plasmic reticulum appearing in the axon terminal following stimulation in the rat sympathetic ganglion in situ. Biomed Res. 6: 13-22 (1985).

Lenz, T. L. and J. Chester: Synaptic vesicle recycling at the neuromuscular junction in the presence of a presynaptic membrane marker. Neuroscience 7: 9-20 (1982).

Matthew, W. D., L. Tsavaler and L. F. Reichardt: Identification of a synaptic vesicle-specific membrane protein with a wide distribution in neuronal and neurosecretory tissue. J. Cell Biol. 91: 257-269 (1981).

Mishell, B. B. and S. M. ShIIGI: Selected methods in cellular immunology. W. H. Freeman and Company, San Francisco, 1981.

Navone, F., R. Jahn, G. Di. Gioia, H. Stukenbrok, P. Greengard and P. De Camilli: Protein p38: an integral membrane protein specific for small vesicles of neurons and neuroendocrine cells. J. Cell Biol. 103: 2511-2527 (1986).

Obata, K., N. KoJima, H. NishiYe, H. Inoue, T. ShiraO, S. C. FUJita and K. UChIzono: Four synaptic vesiclespecific proteins: identification by monoclonal antibodies and distribution in the nervous tissue and the adrenal medulla. Brain Res. 404: 169-179 (1987).
Palay, S. L.: The morphology of synapses in the central nervous system. Exp. Cell Res. Suppl. 5: 275-293 (1958).

Pfeffer, S. R. and R. B. Kelly: The subpopulation of brain coated vesicles that carries synaptic vesicle proteins contains two unique polypeptides. Cell 40: 949-957 (1985).

Rambourg, A. and B. Droz: Smooth endoplasmic reticulum and axonal transport. J. Neurochem. 35: 16-25 (1980).

Reinicke, M. and C. W ALTher: Aspects of turnover and biogenesis of synaptic vesicles at locust neuromuscular junctions as revealed by zinc iodide-osmium (ZIO) reacting with intravesicular SH-groups. J. Cell Biol. 78: 839855 (1978).

Robitaille, R. and J. P. Tremblay: Incorporation of vesicular antigens into the presynaptic membrane during exocytosis at the frog neuromuscular junction. A light and electron microscopy immunochemical study. Neuroscience 21: 619-629 (1987).

Tixier-Vidal, A., A. Faivre-Bauman, R. Picart and B. WiedenmanN: Immunoelectron microscopic localization of synaptophysin in a Golgi subcompartment of developing hypothalamic neurons. Neuroscience 26: 847-861 (1988).

Valtorta, F., R. Jahn, R. Fesce, P. Greengard and B. Ceccarelui: Synaptophysin (p38) at the frog neuromuscular junction: its incorporation into the axolemma and recycling after intense quantal secretion. J. Cell Biol. 107: 2717-2727 (1988).

Von Wedel, R. J., S. S. CARlson and R. B. Kelly: Transfer of synaptic vesicle antigens to the presynaptic plasma membrane during exocytosis. Proc. Nat. Acad. Sci. USA 78: 1014-1018 (1981).

Wiedenmann, B. and W. W. Franke: Identification and localization of synaptophysin, an integral membrane glycoprotein of Mr 38,000 characteristic of presynaptic vesicles. Cell 41: 1017-1028 (1985).

Wiedenmann, B., K. Lawley, C. Grund and D. BRANTON: Solubilization of proteins from bovine brain coated vesicles by protein perturbants and Triton X-100. J. Cell Biol. 101: 12-18 (1985).

Zimmermans, H.: Vesicle recycling and transmitter release. Neuroscience 4: 1773-1804 (1979).

Dr. Tomoko KadOTA

Department of Anatomy

Chiba University School of Medicine Inohana, Chiba

280 Japan

門田朋子

280 千葉市亥鼻 1-8-1

千葉大学医学部

解剖学第一講座 